\title{
Association with the Syndrome "Basses Richesses" of Sugar Beet of a Phytoplasma and a Bacterium-Like Organism Transmitted by a Pentastiridius sp.
}

\author{
F. Gatineau, N. Jacob, S. Vautrin, J. Larrue, J. Lherminier, M. Richard-Molard, and E. Boudon-Padieu
}

First, second, third, fourth, and seventh authors: Epidémiologie des Phytoplasmes, UMR BBCE-IPM, INRA, Université de Bourgogne, Domaine d'Epoisses, BV 86510, 21065 Dijon, Cedex, France; fifth author: Service Commun de Microscopie Electronique, UMR BBCE-IPM, INRA, Université de Bourgogne; and sixth author: Institut Technique de la Betterave Industrielle, 45 rue de Naples, 75008 Paris, France.

Accepted for publication 10 November 2001.

\begin{abstract}
Gatineau, F., Jacob, N., Vautrin, S., Larrue, J., Lherminier, J., RichardMolard, M., and Boudon-Padieu, E. 2002. Association with the syndrome "basses richesses" of sugar beet of a phytoplasma and a bacterium-like organism transmitted by a Pentastiridius sp. Phytopathology 92:384-392.

The syndrome "basses richesses" of sugar beet (SBR) was first observed in 1991 in Burgundy, France. A cixiid planthopper, Pentastiridius beieri, has been proved to be involved in the transmission to sugar beet of a stolbur phytoplasma, which could be detected in some affected plants. In 2000, periwinkle and sugar beet exposed to field-collected cixiids developed symptoms similar to SBR on sugar beet. Use of 4'-6diamidino-2-phenylindole (DAPI) staining and transmission electron

(PCR) analysis. A phloem-restricted gram-negative bacteria was seen in all other plants with symptoms but PCR-negative for phytoplasma. Three primer pairs reported as diagnostic for phloem-limited bacteria were tested but only primers specific for 'Candidatus Phlomobacter fragariae' gave a positive signal, which related to the presence of DAPI-stained bacteria-like objects in diseased plants. Although phytoplasma and bacterium-like organisms were associated with the same macroscopic symptoms on sugar beet, histochemical analysis of phloem cells showed that phytoplasma were associated with cell necrosis and cell wall lignification, while bacteria were associated with these same abnormalities as well as deposit of phenolic compounds in the lumen of phloem cells.
\end{abstract} microscopy confirmed the presence of phytoplasma in some of the plants, which were also positive for this pathogen in a polymerase chain reaction

The sugar beet disease called the "basses richesses" syndrome of sugar beet (SBR) was first described in 1991 in Burgundy in eastern France (25). The disease appeared either in explosive epidemic phases (1991 to 1992, 1996 to 1998) or at lower levels in sparse areas $(1993,1994,1999)$. It causes a loss of root sugar content which can have dramatic economic consequences for growers and the local sugar beet industry: in 1992 the loss of income was $\approx 50 \%$ over 1,000 ha.

SBR symptoms appear in late summer. Affected plants present new shoots with small, narrow leaves and narrow and chlorotic laminae. Old leaves are yellow and necrotic. A brownish discoloration of vascular tissues, seen after cutting the tap root, is the most characteristic symptom of plants affected by SBR.

The possible role of soil and cultivation practices has been investigated and ruled out. There is evidence for aerial transmission, and data suggesting implication of a stolbur phytoplasma in the disease have been reported (25). Epidemiological studies in sugar beet plots affected by SBR have shown that a previously undescribed cixiid planthopper, tentatively identified as Pentastiridius beieri (Wagner), can be infected by stolbur phytoplasma and can transmit it to sugar beet (13). Experiments with natural populations of $P$. beieri containing stolbur phytoplasma-infected specimens reproduced symptoms of SBR on sugar beet in a low proportion $(6 \%)$ of stolbur phytoplasma-positive plants (F. Gatineau, unpublished data). Although these data confirmed the vector role

Corresponding author: E. Boudon-Padieu; E-mail address: boudon@epoisses.inra.fr

Publication no. P-2002-0205-01R

(C) 2002 The American Phytopathological Society
Additional keyword: histochemistry. of $P$. beieri and the implication of a stolbur phytoplasma in SBR, they did not support a major etiological role of a phytoplasma in the disease.

Preliminary microscopic observations of tap root vascular tissues of SBR-affected sugar beet from the field, and of plants exposed to wild insects and subsequently showing symptoms similar to SBR, suggested that another phloem-restricted organism, a bacterium-like organism (BLO), might have a role in the disease (F. Gatineau, unpublished data). In the present article, we have tested this hypothesis by cytological and molecular investigations of sugar beet plants that were naturally affected by SBR or exposed to wild $P$. beieri and showed disease symptoms.

\section{MATERIALS AND METHODS}

$P$. beieri trappings and transmission experiments. Weekly trappings of $P$. beieri were made in 2000 with a self-made aspirating device from June (week 24) to August (week 31) in one sugar beet crop in the Doubs region and one in Sâone-et-Loire, France, in areas severely affected by SBR since 1996.

All transmission experiments were performed in a controlledenvironment insectarium $\left(22^{\circ} \mathrm{C}\right.$, photoperiod $16 \mathrm{~h}$ light, $8 \mathrm{~h}$ dark, humidity $80 \%$ ). Depending on the abundance of $P$. beieri populations at each site and on each date, captured specimens were grouped together as 10 to 80 individuals in caged containers planted with one healthy 2-month-old seedling of sugar beet (Beta vulgaris) and periwinkle (Catharantus roseus). Insects were left on the plants until they died. Dead insects were collected daily and individually stored at $-20^{\circ} \mathrm{C}$ in separate tubes for subsequent phytoplasma detection. When all insects in a batch were dead, the sugar beet and periwinkle plants were separated and transplanted 
into individual containers, placed in a greenhouse, and monitored for symptoms.

Symptom notation on plants. Sugar beet plants used for transmission experiments were examined for tap root symptoms during September when symptoms of SBR appeared in the two plots where the insects had been captured. In addition, six sugar beet plants with typical symptoms of SBR on leaves were uprooted from each of the two plots, transplanted into containers in the greenhouse, and their tap root symptoms evaluated. Periwinkle plants used for transmission experiments also were monitored for physiological disorders.

Light microscopy. Histochemical analysis. Samples were taken from tap roots of SBR-affected field sugar beet plants, insect-exposed sugar beet plants, and healthy control plants not exposed to insects. Sections $(25 \mu \mathrm{m})$ of frozen vascular tissue of tap roots were cut at $-20^{\circ} \mathrm{C}$ with a cryostat (Leica, RueilMalmaison, France). Lignin compounds were visualized with Mirande's reagent (11). Sections were immersed in sodium hypochlorite (48\% active chlorine) for $5 \mathrm{~min}$, rinsed with distilled water, immersed for $5 \mathrm{~min}$ in a solution of carmine 40 and iodine green (Prolabo, Paris, France), and rinsed in distilled water. Lignins also were visualized on adjacent sections with phloroglucinol-HCl coloration (12). Sections were immersed in $10 \%$ phloroglucinol (Prolabo) in absolute ethanol, then washed in $37 \% \mathrm{HCl}$ and mounted on glass slides in a $15 \%$ glycerol solution. Sections were examined by light microscopy (Leica). Autofluorescence of unstained adjacent sections was monitored using UV epifluorescence microscopy with 365-nm excitation and 400-nm barrier filters (A filter; Leica).

4'-6-Diamidino-2-phenylindole (DAPI) staining. DAPI is a DNA-specific fluorochrome suitable for staining phytoplasma DNA $(6-8,28)$ and BLO DNA $(22,23)$ in phloem tissue of infected plants. Samples were taken from 5 plants each of healthy control periwinkle and sugar beet not exposed to insects, from 12 field sugar beet plants with symptoms, and from both plants used in transmission experiments. Frozen sections $(25 \mu \mathrm{m})$ of periwinkle stems and vascular tissue from sugar beet tap roots were cut at $-20^{\circ} \mathrm{C}$ with a cryostat. Sections were mounted on glass slides in a solution of DAPI at $0.1 \mu \mathrm{g} / \mathrm{ml}$ and examined with epifluorescence microscopy under UV light using 365-nm excitation and 400-nm barrier filters.

Transmission electron microscopy. Samples of excised vascular tissue from sugar beet tap roots were fixed overnight at $4^{\circ} \mathrm{C}$ in $2.5 \%$ glutaraldehyde in $0.1 \mathrm{M}$ phosphate buffer, $\mathrm{pH}$ 7.2. The samples were then fixed in $0.5 \%$ OsO4 in $0.1 \mathrm{M}$ phosphate buffer, $\mathrm{pH} 7.2$, for $1 \mathrm{~h}$, washed four times with phosphate buffer, dehydrated through graded concentrations of ethanol, transferred to propylene oxide, and embedded in Epon 812 (Merck, Lyon, France). Ultrathin sections were stained with $3 \%$ uranyl acetate in ethanol and lead citrate (24). Alternatively, ultrathin sections were stained with periodic acid-thiocarbohydrazide-silver proteinate (PATAg) as described by Thiéry (30). Sections were examined with a transmission electron microscope (H-7500, Hitachi, Tokyo) at $80 \mathrm{kV}$.

PCR detection of phytoplasma and BLO. Fresh periwinkle stem pieces and fresh excised vascular tissues of sugar beet tap root of plants previously examined with DAPI staining were processed for phytoplasma and BLO detection assays by PCR. Whole insects that had been deep-frozen after feeding on test plants also were individually submitted to phytoplasma detection assays by PCR.

DNA extraction from plants and insects. Total DNA was extracted from periwinkle tissues and from insects with cethyltrimethylammonium bromide buffer (CTAB) as described by Gatineau et al. (13). The same procedure was used for sugar beet except that DNA was extracted from 0.1 to $0.2 \mathrm{~g}$ of excised tap root vascular tissue ground in $0.5 \mathrm{ml}$ of CTAB buffer with $10 \% \beta$ mercaptoethanol.
PCR detection of phytoplasma in plants and insects. Two pairs of primers designed to amplify $16 \mathrm{~S}$ ribosomal DNA (rDNA) in all known phytoplasmas were used in a nested procedure described by Gatineau et al. (13). P1 (10) and P7 (29) was the first primer pair and fU5 and rU3 (19) the second, giving an expected amplification product of $0.860 \mathrm{~kb}$. PCR procedures and restriction fragment length polymorphism (RFLP) analysis using Tru9I were the same as those described formerly for phytoplasma characterization (13).

PCR detection of BLO in plants. Total DNA extracts of all plants tested by PCR for phytoplasma also were assayed for BLO using three independent PCR procedures, each with a different primer pair. PCR amplification assays were performed in $40 \mu \mathrm{l}$ of

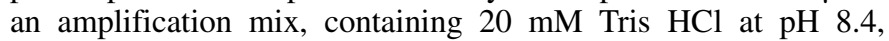

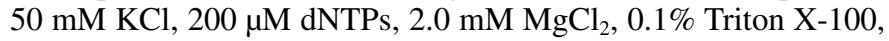
bovine serum albumin (BSA) at $200 \mu \mathrm{g} / \mathrm{ml}, 2$ units of Taq DNA polymerase (Q. BIOgene, Illkirch, France), and $2 \mu$ of extracted DNA.

In procedure 1, primers OI1-OI2c, constructed for specific detection of $16 \mathrm{~S}$ rDNA of the BLO associated with the greening disease of citrus (18), were used at $1.0 \mu \mathrm{M}$. Amplification conditions were a predenaturation step for $20 \mathrm{~min}$ at $92^{\circ} \mathrm{C}$, then 40 cycles of $60 \mathrm{~s}$ at $92^{\circ} \mathrm{C}, 45 \mathrm{~s}$ at $47^{\circ} \mathrm{C}$, and $90 \mathrm{~s}$ at $72^{\circ} \mathrm{C}$, followed by a final elongation step for $15 \mathrm{~min}$ at $72^{\circ} \mathrm{C}$. Taq DNA polymerase was added after the predenaturation step. In procedure 2, primers YV1-YV3, constructed for specific detection of $16 \mathrm{~S}$ rDNA of BLO associated with yellow vine disease of cucurbits (1), were used at $1.0 \mu \mathrm{M}$. The amplification program consisted of a predenaturation step for $10 \mathrm{~min}$ at $92^{\circ} \mathrm{C}$, then 30 cycles of $60 \mathrm{~s}$ at $92^{\circ} \mathrm{C}, 45 \mathrm{~s}$ at $60^{\circ} \mathrm{C}$, and $90 \mathrm{~s}$ at $72^{\circ} \mathrm{C}$. Taq DNA polymerase was added after the predenaturation step. In procedure 3, primers Fra4Fra5, constructed for specific detection of $16 \mathrm{~S}$ rDNA of the BLO 'Candidatus Phlomobacter fragariae' associated with marginal chlorosis of strawberry (32), were used at $1.0 \mu \mathrm{M}$. The amplification program consisted of 35 cycles of $60 \mathrm{~s}$ at $92^{\circ} \mathrm{C}, 60 \mathrm{~s}$ at $52^{\circ} \mathrm{C}$, and $60 \mathrm{~s}$ at $72^{\circ} \mathrm{C}$. Amplification products were analyzed by electrophoresis and UV light visualization according to standard procedures (13).

Controls for PCR assays. Samples of DNA extracted from healthy sugar beet and periwinkle seedlings, from periwinkle plants infected with apple proliferation (AP) and stolbur (STOL C) phytoplasma (27), from strawberry infected with 'Candidatus Phlomobacter fragariae' (provided by CIREF, Lanxade, France), and from watermelon infected with the BLO associated with yellow vine disease of cucurbits (provided by B. D. Bruton, USDAARS, Oklahoma), served as PCR controls for all detection assays in plants.

Samples of DNA extracted from specimens of phytoplasmainfected Euscelidius variegatus Kbm leafhoppers, obtained by feeding healthy leafhoppers on clover phyllody (Phi) phytoplasmainfected broad bean plants $(5,13)$, served as positive PCR controls for phytoplasma detection assays in insects. Negative controls were DNA extracted from healthy specimens of E. variegatus, hatched and reared in our insectary.

\section{RESULTS}

Transmission experiments and symptom notation on plants. Enough insects were captured during 7 weeks to constitute 27 batches of 10 to 80 individuals. Twenty batches of insects captured from Sâone-et-Loire were placed on 20 sugar beet-periwinkle couples and seven batches of insects captured from the Doubs were placed on 7 sugar beet-periwinkle couples. Results of transmission experiments and symptom rating are given in Table 1. Among the 27 periwinkle plants exposed to insects, 23 were still alive when observations for symptoms were made. Two categories of plants were annotated: healthy plants $\left(\mathrm{S}_{-}-\right.$) with normal vegetation compared with five healthy control plants not exposed to 
insects, and symptomatic plants $(\mathrm{S}+)$ with physiological disorders like wilting, yellow spots on leaves, and reduction in flower size. Ten plants were noted as $\mathrm{S}-$ and 13 as $\mathrm{S}+$. Among the latter plants, one periwinkle, which had been exposed to the 26th batch of insects, had slightly different symptoms, including virescence of flower petals and curling of the leaves; this plant was noted as S+*. Among 27 sugar beets that had been exposed to insects, 22 were still alive when examined in September. Two categories of plants were annotated in comparison with five healthy control plants that had not been exposed to insects: plants with normal tap root vascular tissues (TS-), and plants with brown, discolored tap root vascular tissues (TS+). Of these plants, 3 were noted as TSand 19 as TS+. All 12 sugar beet plants with SBR symptoms from the Doubs and Sâone-et-Loire sites had brown, discolored tap root vascular tissues and were noted as TS+.

Histochemistry of sugar beet tissue. All unstained tap root sections of SBR-affected sugar beet plants from the field observed by bright field microscopy had phloem cells with a brownish discoloration of their walls and brown deposits in their lumen. In addition, a few cells had collapsed in all plants (Fig. 1A). These symptoms also were observed in all insect-exposed sugar beet plants rated as TS+, except for one. The latter, which had been exposed to the 26th batch of insects, similarly had some collapsed phloem cells and brownish phloem cell walls, but had no brown

TABLE 1. Detection of phytoplasma on Pentastiridius beieri specimens trapped in Sâone-et-Loire and Doubs, France, and insect transmission to periwinkle and sugar beet

\begin{tabular}{|c|c|c|c|c|}
\hline \multirow[b]{2}{*}{ Location, batch no. } & \multirow[b]{2}{*}{ Capture week } & \multirow[b]{2}{*}{ Total/tested ${ }^{\mathrm{a}}$} & \multicolumn{2}{|c|}{ Symptom rating ${ }^{\mathrm{b}}$} \\
\hline & & & Periwinkle & Sugar beet \\
\hline Sâone-et-Loire & June & & & \\
\hline 1 & 24 & $13 / 4$ & S+ & TS+ \\
\hline 2 & 25 & $8 / 4$ & Dead & TS- \\
\hline \multirow[t]{2}{*}{3} & 26 & $20 / 11$ & Dead & TS+ \\
\hline & July & & & \\
\hline 4 & 27 & $50 / 30$ & S+ & TS+ \\
\hline 5 & 27 & $50 / \mathrm{NT}$ & $\mathrm{S}+$ & $\mathrm{TS}+$ \\
\hline 6 & 27 & $42 / 23$ & $\mathrm{~S}_{-}$ & Dead \\
\hline 7 & 27 & $40 / 26$ & S- & TS+ \\
\hline 8 & 27 & $39 / 23$ & $\mathrm{~S}+$ & TS+ \\
\hline 9 & 27 & $39 / 29$ & $\mathrm{~S}+$ & Dead \\
\hline 10 & 28 & $19 / 19$ & Dead & TS+ \\
\hline 11 & 29 & $46 / 21$ & $\mathrm{~S}+$ & $\mathrm{TS}+$ \\
\hline 12 & 29 & $43 / 24$ & S- & $\mathrm{TS}+$ \\
\hline 13 & 29 & $48 / 32$ & S- & $\mathrm{TS}+$ \\
\hline 14 & 29 & $48 / 31$ & S- & $\mathrm{TS}+$ \\
\hline 15 & 29 & $41 / 41$ & $\mathrm{~S}_{-}$ & $\mathrm{TS}+$ \\
\hline 16 & 30 & $70 / 60$ & $\mathrm{~S}-$ & Dead \\
\hline \multirow[t]{2}{*}{17} & 30 & $62 / 54$ & S+ & TS+ \\
\hline & August & & & \\
\hline 18 & 31 & $50 / 29$ & S- & TS- \\
\hline 19 & 31 & $52 / 25$ & $\mathrm{~S}-$ & TS- \\
\hline 20 & 31 & $79 / 20$ & S+ & TS+ \\
\hline Doubs & June & & & \\
\hline 21 & 24 & $14 / 2$ & S+ & TS+ \\
\hline 22 & 24 & $48 / 39$ & $\mathrm{~S}+$ & TS+ \\
\hline 23 & 25 & $8 / 2$ & $\mathrm{~S}+$ & Dead \\
\hline 24 & 25 & $31 / 20$ & Dead & $\mathrm{TS}+$ \\
\hline 25 & 26 & $20 / 1$ & $\mathrm{~S}_{-}$ & Dead \\
\hline 26 & 26 & $30 / 28$ & $\mathrm{~S}+*$ & TS+ \\
\hline 27 & 26 & $35 / 17$ & S+ & TS+ \\
\hline \multirow[t]{3}{*}{ Total } & $\ldots$ & $1,045 / 622^{\mathrm{c}}$ & $10 \mathrm{~S}-$, & \\
\hline & & & $12 \mathrm{~S}+$, & 3 TS-, \\
\hline & & & $1 \mathrm{~S}+*$ & $19 \mathrm{TS}+$ \\
\hline
\end{tabular}

a Total number of $P$. beieri caged on plants/total number recovered and tested for phytoplasma. NT $=$ not tested.

${ }^{\mathrm{b}} \mathrm{S}+=$ periwinkle with wilting, yellow spots on the leaves and reduction in flower size; $\mathrm{S}^{*}=$ periwinkle with virescence of flower petals and curling of the leaves; $\mathrm{S}_{-}=$= periwinkle without physiological disorders; TS $+=$sugar beet with tap root symptoms; TS- = sugar beet without tap root symptoms.

c Total number of $P$. beieri that tested positive by polymerase chain reaction for phytoplasma detection $=0$. deposit in the lumen of phloem cells (Fig. 1B). These symptoms were not observed in plants that had been exposed to insects but rated as TS- and in healthy control plants (Fig. 1C). Secondary walls of xylem vessels of all plants (TS+, TS-, and healthy controls) fluoresced bright blue under UV light (Fig. 1D, E, and F). In sugar beet plants rated as TS+ (i.e., SBR-affected plants from the field) (Fig. 1D) and those that had been exposed to insects, including the plant exposed to the 26th batch of insects (Fig. 1E), phloem cell walls had a blue-white fluorescence. The deposits in the lumen of phloem tubes, previously observed with white light, did not fluoresce or had a faint brownish orange fluorescence (Fig. 1D). Phloem cell walls of plants rated as TS- that had been exposed to insects, and of healthy control plants, did not fluoresce either on phloem cell walls or in the lumen (Fig. 1F). In all plants rated as TS+ (i.e., SBR-affected ones from the field and those that had been exposed to insects), cell walls of some phloem tubes and intercellular spaces were stained red or green with phloroglucinol (Fig. 1G) or Mirande's reagent (Fig. 1H), respectively. Deposits observed in the lumen of some phloem cells were also stained red or green with phloroglucinol (Fig. 1G) or with Mirande's reagent (Fig. 1H), respectively. No similar staining was observed in the phloem of plants without symptoms (TS-), either exposed to insects or healthy controls.

Detection by DAPI staining of phloem-restricted organisms. Results of DAPI staining are given in Table 2. Fluorescence was observed in internal and external rings of phloem tubes from all periwinkle plants, which had been exposed to insects and showed symptoms, and in the lumen of phloem tubes from all sugar beet plants with SBR symptoms, whether exposed to insects or from the field. No such fluorescence was observed in healthy control plants and in symptomless plants exposed to insects. Similar fluorescence was not observed in any other tissue (xylem or parenchyma) of any examined plants.

The fluorescence observed in the phloem of field plants or plants exposed to insects was in the form of elongated rods (Fig. 2A). The periwinkle plant rated $\mathrm{S}^{*}$ and the partner sugar beet plant rated TS+ had a slightly different fluorescent signal in the form of individual spherical structures (Fig. 2B).

Transmission electron microscopy observations of vascular tissues. Transmission electron microscopy (TEM) observations of tap root vascular tissues of SBR-affected sugar beet from the field confirmed the presence of elongated structures, as previously observed with UV-light microscopy after DAPI staining (Fig. 3A and B). These were bacilliform and were restricted to phloem sieve tubes. They were 0.28 to $0.32 \mu \mathrm{m}$ in diameter and 2 to $2.5 \mu \mathrm{m}$ in length (Fig. 3A and B), and a few showed signs of cell constriction (Fig. 3A). The envelope of these BLOs was $\approx 33 \mathrm{~nm}$ thick, consisting of an internal cytoplasmic membrane and an external cell wall separated by an electron translucent 12-nmwide interspace (Fig. 3C). There was no evidence from PATAg staining of the presence of a mucocomplex at the surface of the external cell wall (Fig. 3D). Sieve pores were obstructed by electron-dense material in phloem sieve tubes containing BLOs (Fig. 3B).

TEM observations of tap root vascular tissues of the symptomatic sugar beet plant exposed to the 26th batch of insects revealed the presence of pleomorphic wall-less organisms with typical phytoplasma features in some phloem cells (Fig. 3E).

Phytoplasma detection in insects and plants by PCR. A DNA fragment of the expected size was obtained by PCR using DNA from Phi-infected E. variegatus. No amplification product was obtained using DNA from healthy E. variegatus (data not shown) nor using DNA from the 622 P. beieri specimens tested (Table 1).

PCR products from plants using fU5-rU3 primers are shown in Figure 4A. No signal was obtained from the healthy periwinkle and sugar beet DNA controls nor from the two BLO DNA controls. An amplification product of the expected size was obtained 

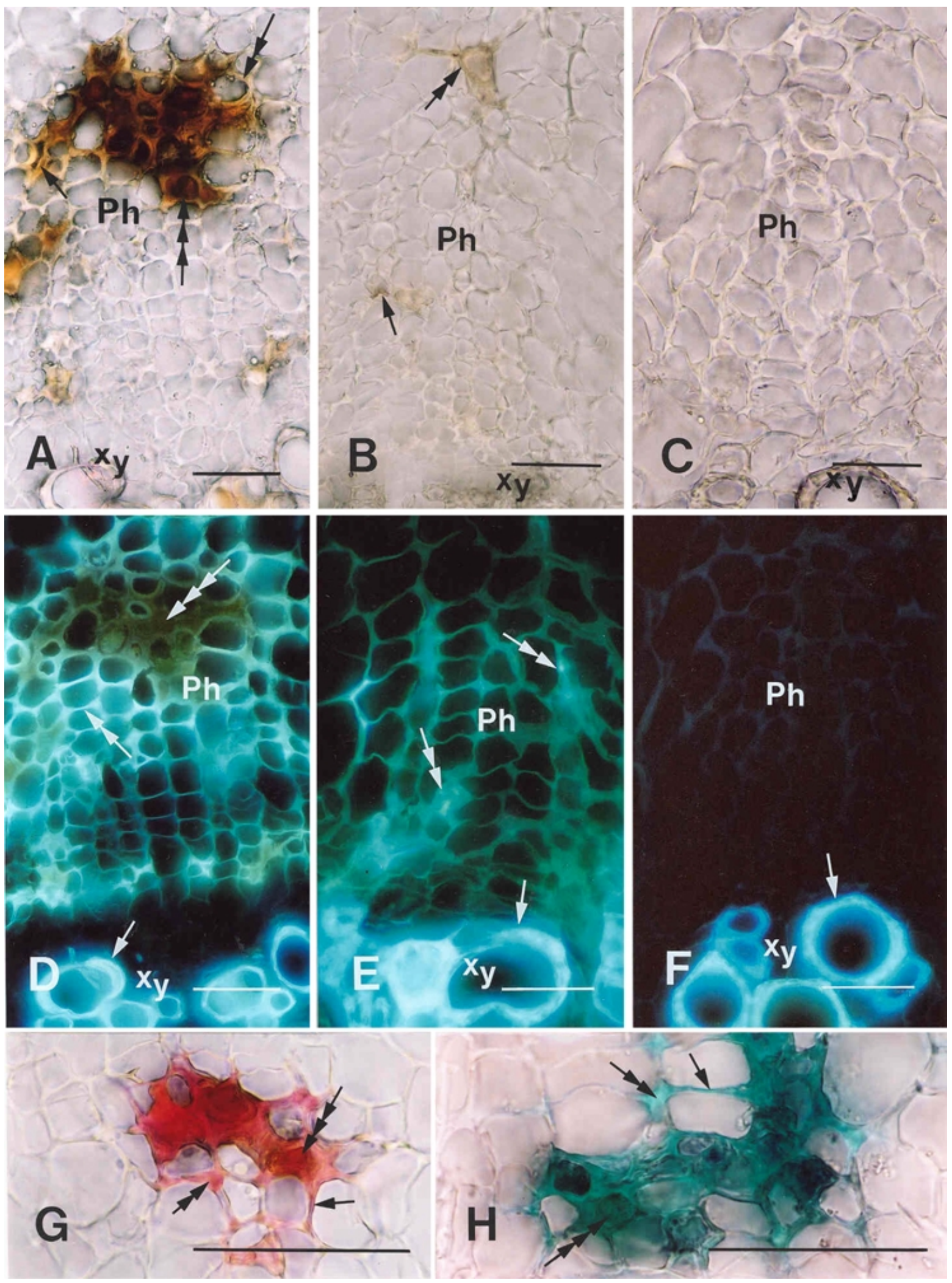

Fig. 1. Observations with A, B, C, G, and H, bright field and D, E, and F, UV-light microscopy of transverse sections of tap root vascular tissue of $\mathbf{A}$, D, G, and $\mathbf{H}$, "basses richesses" syndrome (SBR)-affected sugar beet grown in the field, B and E, SBR-affected sugar beet exposed to the 26th batch of Pentastiridius beieri, and $\mathbf{C}$ and $\mathbf{F}$, healthy control sugar beet. A, B, and C, unstained sections. A and B, In SBR-affected sugar beet, note the presence of some collapsed cells (arrow) in the phloem tissue $(\mathrm{Ph})$ and the brown discoloration of some cell walls (double arrow) which are not observable in $\mathbf{C}$, healthy phloem tissue. The deposition of brown compounds in the lumen of some phloem cells (triple arrow) is not observable in the phloem tissue B, from the plant exposed to the 26th batch of insects and $\mathbf{C}$, from healthy control plants; $\mathbf{D}, \mathbf{E}$, and $\mathbf{F}$, unstained sections. The blue-white autofluorescence $\mathbf{D}, \mathbf{E}$, and $\mathbf{F}$, (arrow) of secondary walls of xylem vessels and $\mathbf{D}$ and $\mathbf{E}$, (double arrow) of the walls of some phloem cells from plants with symptoms indicates the presence of lignin. Such fluorescence is absent from the phloem tissue of $\mathbf{F}$, healthy control plants. The brown deposits in the lumen of some phloem tubes of plants from the field, previously observed A, in same section with white light, do not fluoresce D, under UV light or have a weak brownish-orange fluorescence, indicating lignin-derived products (triple arrow). The red or green coloration in sections stained with $\mathbf{G}$, phloroglucinol- $\mathrm{HCl}$ or $\mathbf{H}$, Mirande's green indicates the presence of lignin-derived products on the walls of some phloem cells (arrow), in the intercellular spaces (double arrow) and also in the lumen of some phloem cells (triple arrow). Bars $=10 \mu \mathrm{m}$. 
from the AP and STOL C phytoplasma controls and from DNA of some of the tested plants. Results obtained for all the tested plants are summarized in Table 2. Among the periwinkle plants exposed to insects and showing physiological disorders, only the $\mathrm{S}+*$ plant exposed to the 26th batch of insects was positive for phytoplasma detection. Similar results were obtained for insect-exposed sugar beet in that only the plant rated TS+ and exposed to the 26th batch of insects was positive for presence of phytoplasma. Tests of all the TS+ sugar beet plants from the field were negative. RFLP analysis using Tru9I of fU5-rU3 fragments from the PCR-positive periwinkle and sugar beet plants gave a DNA profile similar to the reference profile of STOL C but different from the reference profile of AP (Fig. 4B).

BLO detection in plants by PCR. Results obtained for all the tested plants are summarized in Table 2 . No amplification product was obtained using procedure 1 (OI1-OI2c primers) with DNA from any periwinkle and sugar beet plant, nor from BLO-infected strawberry and watermelon or periwinkle-maintained reference phytoplasmas (data not shown). Procedure 2 (YV1-YV3 primers) gave a PCR product of the expected size with the BLO-infected watermelon DNA (data not shown) but not with DNA from any of the periwinkle or sugar beet plants.

PCR products obtained with procedure 3 (Fra4-Fra5 primers) are shown in Figure 4C. No amplification product was obtained with control DNA of cucurbits yellow vine agent, nor with DNA from AP and STOL C phytoplasma-infected periwinkles or from healthy control periwinkle and sugar beet. An amplification product of the expected size was obtained with control DNA of strawberry affected by marginal chlorosis and with all DNAs from SBR-affected sugar beet from the field. All TS+ sugar beet and all $\mathrm{S}+$ periwinkle plants exposed to insects were PCR-positive for BLO, except for the TS+ sugar beet and the S+* periwinkle plants exposed to the 26th batch of insects, both of which had given positive results for phytoplasma detection. Overall, 18 out of 22 sugar beet $(81.8 \%)$ and 12 out of 23 periwinkle $(52.2 \%)$ plants exposed to insects were BLO-infected.

\section{DISCUSSION}

Symptoms of SBR and symptom reproduction. Phloemrestricted pathogens, such as phytoplasmas, BLOs, and some viruses, cause stunting, proliferation, uneven expansion and discoloration of the laminae of young leaves, leaf curling and twisting, virescence of flower petals, and, most often, the premature death of the entire plant $(17,21)$. Some of these symptoms were observed on the SBR-affected sugar beet plants from the field: new shoots with small narrow leaves, narrow and chlorotic laminae, and yellow and necrotic old leaves. In addition, a honeybrown discoloration of tap root vascular tissues was observed in
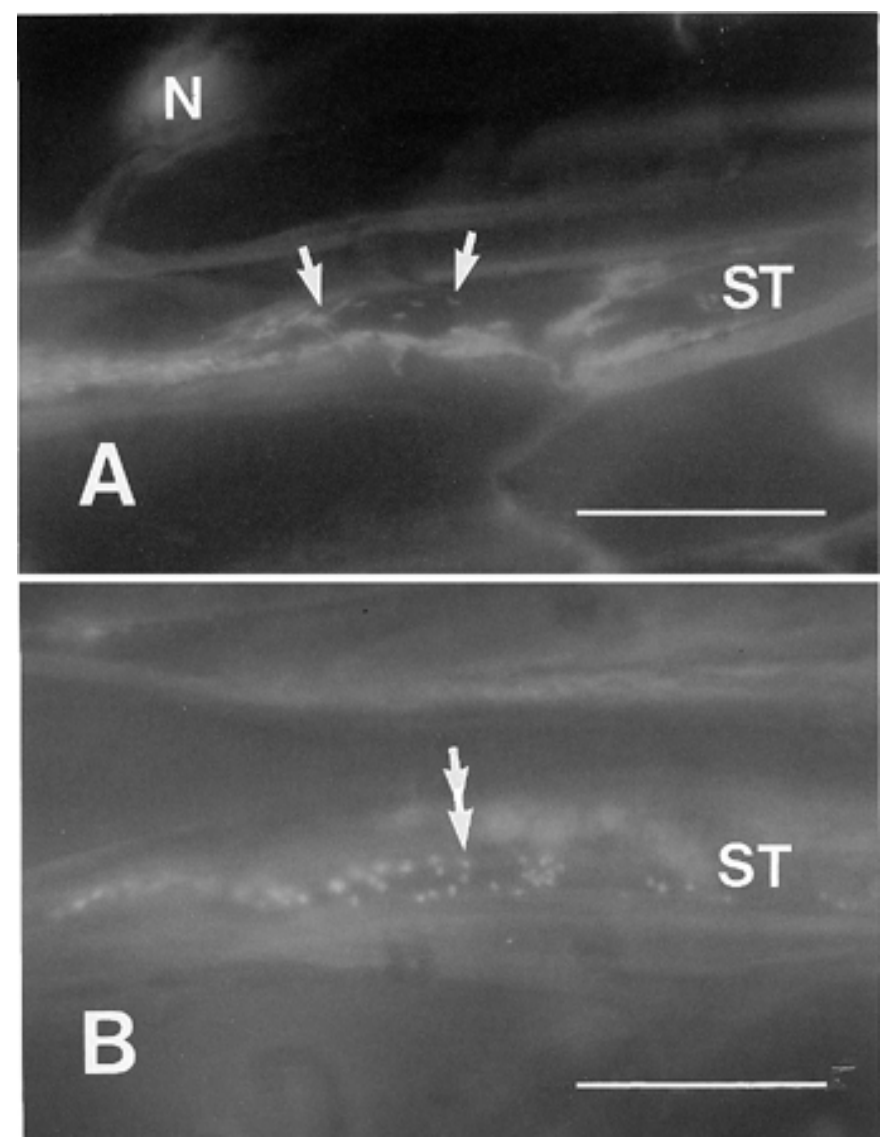

Fig. 2. Observations under UV-light microscopy of 4'-6-diamidino-2phenylindole-stained longitudinal sections of phloem tissue of sugar beet that had been exposed to Pentastiridius beieri and that had developed symptoms of sugar beet "basses richesses" syndrome. A, View of a sieve tube (ST) with lumen containing bacilliform bacterium-like organisms (BLO) (arrow); $\mathrm{N}=$ nucleus of an adjacent parenchyma cell. B, View of a ST of sugar beet exposed to the 26th batch of insects; spherical organisms resembling phytoplasma fluoresce (double arrow) in the lumen of the cell. Bars $=10 \mu \mathrm{m}$.

TABLE 2. Results of 4'-6-diamidino-2-phenylindole (DAPI) staining and polymerase chain reaction assays for phytoplasma and bacterium-like organisms (BLOs) in periwinkle (PW) and sugar beet (SB) plants exposed to wild Pentastiridius beieri specimens, in healthy periwinkle and sugar beet plants not exposed to $P$. beieri, and in "basses richesses" syndrome affected sugar beet from the field

\begin{tabular}{|c|c|c|c|c|c|c|c|c|}
\hline \multirow[b]{2}{*}{ Assay } & \multirow[b]{2}{*}{ Results $^{\mathrm{a}}$} & \multicolumn{2}{|c|}{ Insect-exposed $\mathrm{PW}^{\mathrm{b}}$} & \multirow{2}{*}{$\frac{\text { Nonexposed PW }}{(n=5)}$} & \multicolumn{2}{|c|}{ Insect-exposed $\mathrm{SB}^{\mathrm{c}}$} & \multirow{2}{*}{$\frac{\text { Nonexposed SB }}{(n=5)}$} & \multirow{2}{*}{$\begin{array}{c}\text { SB from field } \\
\mathrm{TS}+(n=12)\end{array}$} \\
\hline & & $S+$ and $S+*(n=13)$ & $\mathrm{S}-(n=10)$ & & $\mathrm{TS}+(n=19)$ & $\mathrm{TS}-(n=3)$ & & \\
\hline \multirow[t]{2}{*}{ DAPI staining } & + & 13 & 0 & 0 & 19 & 0 & 0 & 12 \\
\hline & - & 0 & 10 & 5 & 0 & 3 & 5 & 0 \\
\hline \multirow[t]{2}{*}{ P1-P7 / U5-U3 } & + & $1^{\mathrm{d}}$ & 0 & 0 & $1^{\mathrm{d}}$ & 0 & 0 & 0 \\
\hline & - & 12 & 10 & 5 & 18 & 3 & 5 & 12 \\
\hline \multicolumn{9}{|l|}{ BLO detection } \\
\hline \multirow[t]{2}{*}{ Procedure 2, YV1-YV3 } & + & 0 & 0 & 0 & 0 & 0 & 0 & 0 \\
\hline & - & 13 & 10 & 5 & 19 & 3 & 5 & 12 \\
\hline \multirow[t]{2}{*}{ Procedure 3, Fra4-Fra5 } & + & 12 & 0 & 0 & 18 & 0 & 0 & 12 \\
\hline & - & $1^{\mathrm{d}}$ & 10 & 5 & $1^{\mathrm{d}}$ & 3 & 5 & 0 \\
\hline
\end{tabular}

a Test results: $+=$ positive for the test and - negative for the test.

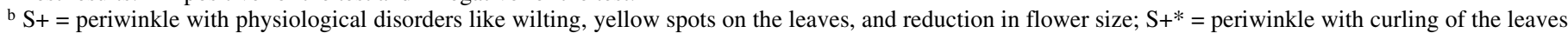
and virescence; $S_{-}=$periwinkle without physiological disorders.

c $\mathrm{TS}+=$ sugar beet with tap root symptoms; TS- = sugar beet without tap root symptoms.

${ }^{\mathrm{d}}$ Periwinkle and sugar beet partners both exposed to the 26 th batch of insects. 
all plants. Such honey-brown discoloration of vascular tissues has been reported on cucurbits affected by the yellow vine disease, associated with a phloem-restricted bacteria (4). TS+ sugar beet plants had corresponding cytological symptoms of necrosis of some phloem tubes, lignification of phloem cell walls, as demonstrated by autofluorescence and staining by phloroglucinol or
Mirande's green, and deposits of compounds in the lumen of phloem cells. These observations of macroscopic and cytological symptoms clearly support the early hypothesis that SBR could be classified as a disease affecting phloem.

By exposing healthy sugar beet seedlings to feeding by wild Pentastiridius specimens, we obtained a large number of plants

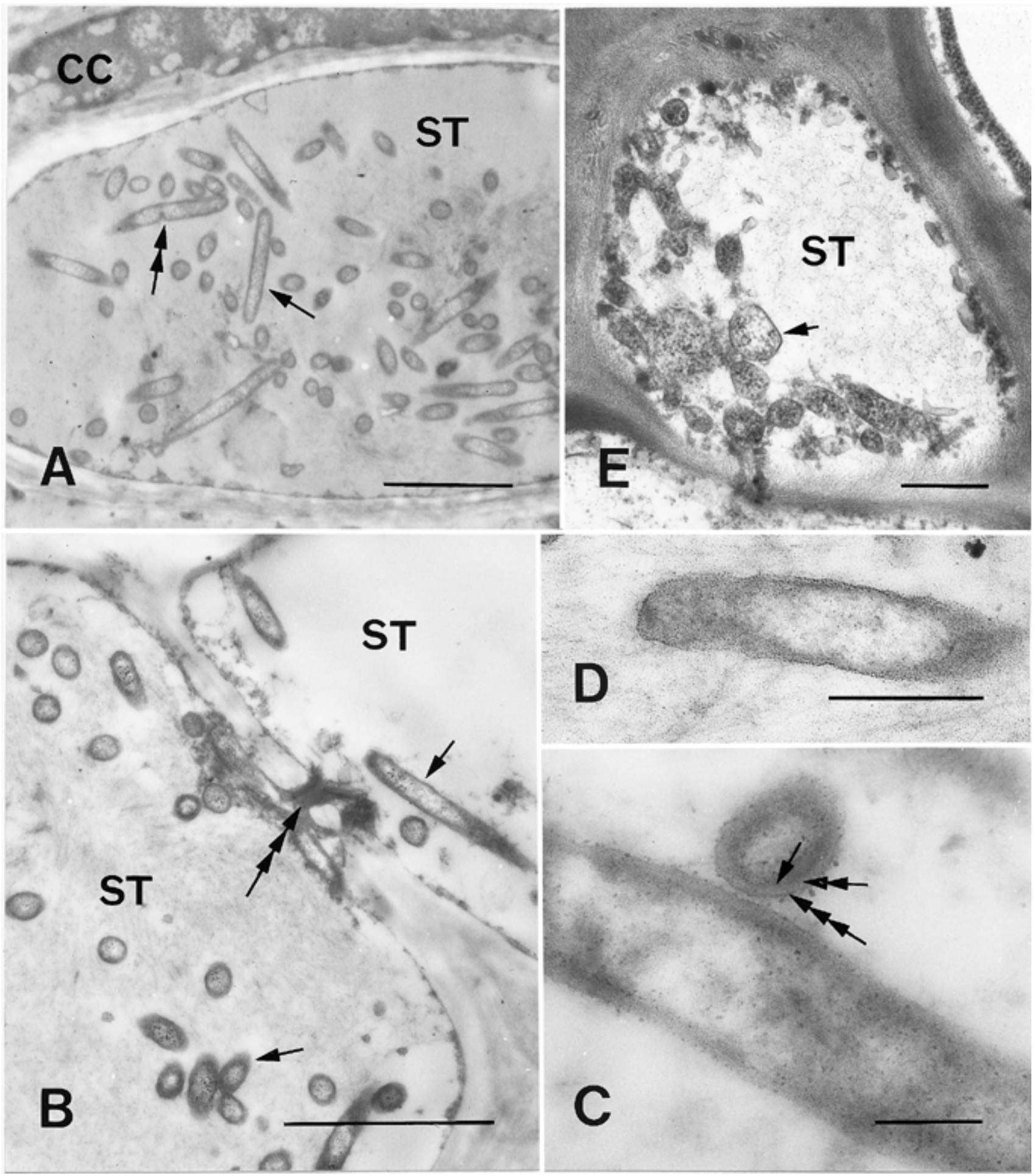

Fig. 3. Transmission electron microscopy micrographs of sieve tube (ST) sections of "basses richesses" syndrome-affected field-grown sugar beet, colonized by bacterium-like organisms (BLO) (arrow). A, Transverse section: the double arrow indicates constriction of a BLO; CC = companion plant cell. B, Longitudinal section: some sieve pores are obstructed by electron-dense material (triple arrow). Bars $=2 \mu \mathrm{m}$. C, Longitudinal and transverse sections of BLOs. The envelope of the organisms was about $33 \mathrm{~nm}$ thick, consisting of an internal cytoplasmic membrane (arrow) separated by an electron translucent 12-nm-wide interspace (double arrow) from an external cell wall (triple arrow). Bar $=200 \mathrm{~nm}$. D, Periodic acid-thiocarbohydrazide-silver proteinate staining of a BLO. There is no external mucocomplex on the outer cell wall. Bar $=0.5 \mu \mathrm{m}$. E, Transverse section stained with uranyl acetate and lead citrate of a sieve tube of the TS+ sugar beet plant exposed to the 26th batch of insects. The lumen of ST is colonized by pleomorphic wall-less organisms with typical phytoplasma features (arrow). Bar $=0.5 \mu \mathrm{m}$. 
(84\%) with macroscopic and microscopic symptoms that were similar, if not identical, to those observed on SBR-affected plants from the field. Pentastiridius-exposed symptomatic plants had the same abnormalities in phloem tissue as SBR-affected plants from the field (i.e., necrosis of some phloem tubes, lignification of their cell walls, and deposition of compounds in their lumen). The only exception was the sugar beet plant exposed to the 26th batch of insects, in that it had the same lignification of phloem cell walls and phloem cell necrosis but no deposition of compounds in phloem tubes.

The similar symptoms observed at the macroscopic level and at the cytological level in plants inoculated during transmission experiments and in naturally SBR-affected plants from the field provide strong evidence that $P$. beieri transmits the SBR causal pathogens to sugar beet.

Association of phloem-restricted organisms with symptoms. DAPI staining applied to vascular tissues of symptomatic insectexposed periwinkle and sugar beet revealed the presence of two types of phloem-restricted organisms. One organism, which TEM observations and PCR detection confirmed as a phytoplasma, was observed only in a couple of plants exposed to the same batch of insects. The other organism, which appeared to be bacilliform, was detected in all the other plants showing symptoms. TEM observations showed that this bacilliform organism had the dimensions, structure, and cell envelope thickness previously described for gram-negative BLOs $(4,16,17,20,23)$. In addition, PATAg staining did not reveal the external mucocomplex on the outer cell wall typical of gram-positive bacteria (14). The PCR primers used distinguished between these two phloem-restricted organisms. RFLP analysis identified one as a stolbur phytoplasma; the other, detected using Fra4-Fra5 primers specific for the marginal chlorosis agent in strawberry, may be related to 'Candidatus Phlomobacter fragariae'. Only the gram-negative BLO related to 'Candidatus Phlomobacter fragariae' was found in SBR-affected sugar beet plants from the field. The two organisms were not detected together, either visually or by PCR in the same symptomatic plant (periwinkle or sugar beet).

There was full correspondence between macroscopic symptoms and visual and PCR detection of BLO or phytoplasma in phloem tubes for all sugar beet plants from the field and for all plants used during our transmission experiments. Although phytoplasma or BLO infection gave different macroscopic symptoms on periwinkle, the two organisms were associated with similar macroscopic symptoms on sugar beet. However, cytological observations showed differences between phytoplasma- and BLO-infected sugar beet plants. Although necrosis and lignification of phloem cell walls was associated with the presence of either of the two organisms, electron-dense deposits in the lumen of some sieve tubes, which have been previously described in other BLOassociated diseases $(3,20)$, were associated only with the presence of BLO. No such deposits were ever observed in sections of phytoplasma-infected sugar beet. Greber and Gwanlock (15) reported a similar differential cytological response of strawberry to phytoplasma and BLO infection. They proposed that the

\section{A}

$\begin{array}{lllllllllllllllllllllll}1 & 2 & 3 & 4 & 5 & 6 & 7 & 8 & 9 & 10 & 11 & 12 & 13 & 14 & 15 & 16 & 17 & 18 & 19 & 20 & 21 & 22 & 23\end{array}$

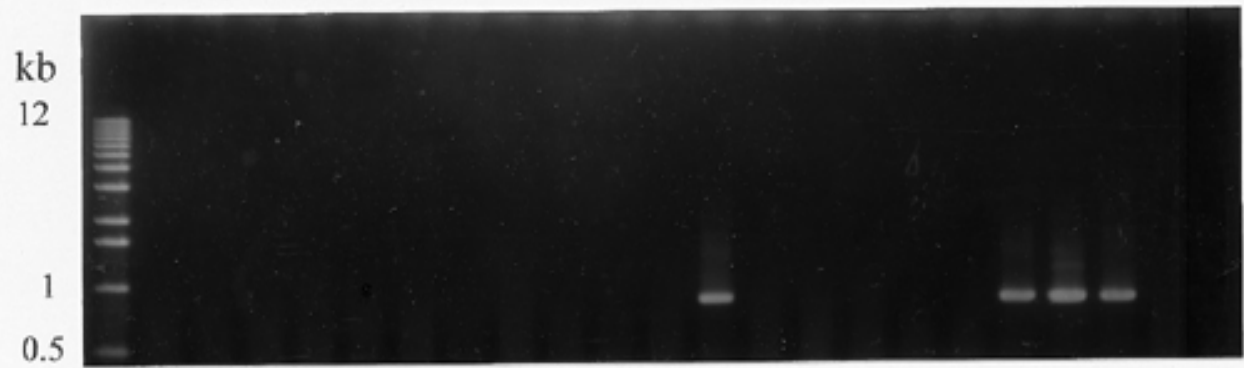

0.5

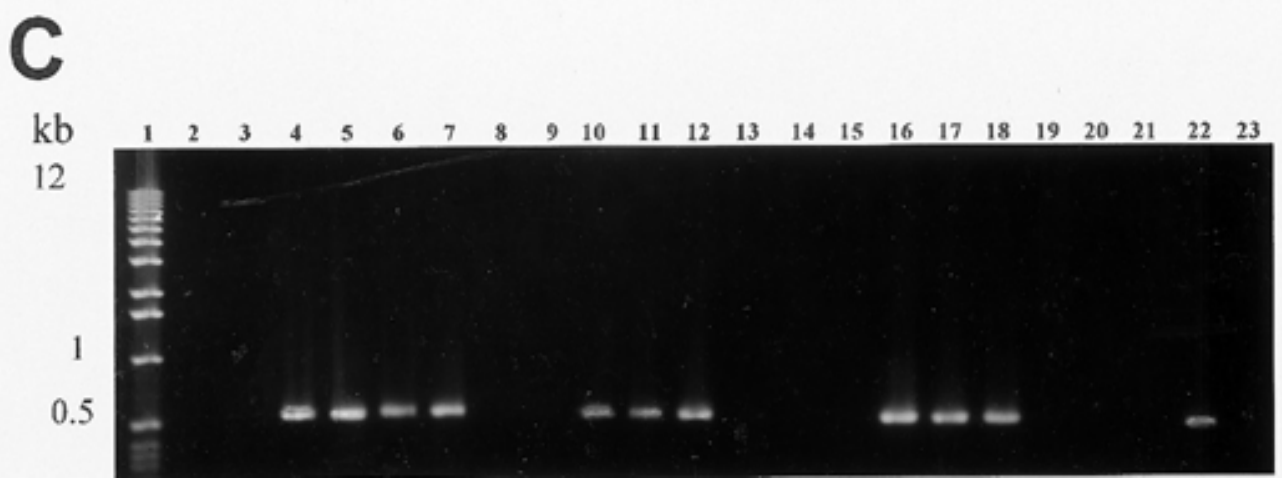

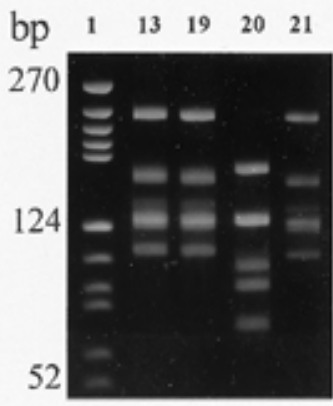

Fig. 4. Analysis of polymerase chain reaction products. A, Agarose electrophoresis of the fU5-rU3 fragment of phytoplasma 16S rDNA; B, the Tru9I restriction profile of amplicons obtained in $\mathbf{A} ; \mathbf{C}$, agarose electrophoresis of the Fra4-Fra5 fragment of bacterium-like organism (BLO) 16S rDNA. Lane 1, A and C, 1-kb molecular weight ladder (BRL); B, pBR322/HaeIII ladder (Appligene). Lane 2, healthy control periwinkle. Lane 3, healthy control sugar beet. Lanes 4, 5, 6, and 7, "basses richesses" syndrome (SBR)-affected sugar beet from the field with tap root symptoms (TS+). Lanes 8 through 19, plants exposed to Pentastiridius beieri: lanes 8 and 9, sugar beet without tap root symptoms (TS-); lanes 10,11,12, and 13, sugar beet noted as TS+; lanes 14 and 15, periwinkle without physiological disorders (S-); lanes 16,17 , and 18, periwinkle with physiological disorders (S+); lane 19, periwinkle exposed to the 26th batch of insects. Lanes 20 and 21, reference phytoplasma strains maintained on periwinkle: lane 20, apple proliferation phytoplasma; lane 21, stolbur phytoplasma. Lanes 22 and 23, BLO-positive controls: lane 22, total DNA of strawberry infected with 'Candidatus Phlomobacter fragariae'; lane 23, total DNA of watermelon infected with the agent of yellow vine disease on cucurbits. 
similarity of macroscopic symptoms resulted from similar localization of the pathogens in phloem tissue and the same type of physiological effects (15). The different structural responses observed (i.e., the necrosis and/or occlusion of phloem vessels) might represent vascular defense reactions that limit the colonization of the pathogens (2) and cause the same physiological perturbations leading to similar macroscopic symptoms.

The presence of phytoplasma and BLO in all naturally SBRaffected sugar beet and insect-inoculated symptomatic plants, their absence from nonsymptomatic plants, and their localization in tissues affected by physiological disturbances support the hypothesis that these phloem-restricted organisms are responsible for the disease symptoms seen on periwinkle and sugar beet. However, definite proof, based on Koch's postulate, is lacking because BLO and phytoplasmas cannot be cultured and experimental rearing of $P$. beieri has not yet been successful.

Several sugar beet diseases have been described and associated with phloem-restricted organisms. A yellow wilt disease in Chile, transmitted by the leafhopper Paratanus exitiosus (B.) has been associated with a phytoplasma (31) tentatively classified in the Western X group (25). The latent rosette disease (LRD) in Germany, transmitted by the leafbug Piesma quadratum Fieb. (Heteroptera) (26), has been associated with BLOs (16). For the latter, leaf but not root symptoms were similar to those of SBR (26). Differences in symptomatology and development conditions of LRD and SBR, as well as the etiology of the two vector insects, which belong to different subclasses, suggest that the BLO associated with LRD and the BLO associated with SBR are different.

Although several plant diseases associated with phloem-restricted BLOs have been reported (9), only three BLOs have been phylogenetically characterized and specifically detected using PCR: Liberibacters (18), 'Candidatus phlomobacter fragariae' (32), and the yellow vine of cucurbits agent (1). In the present work, the positive and specific detections regularly obtained with the primer pair Fra4-Fra5 suggest that the BLO associated with SBR of sugar beet could be related to 'Candidatus phlomobacter fragariae', the agent of marginal chlorosis in strawberry, and therefore, might belong to the $\gamma-3$ subgroup of Proteobacteria.

Vector transmission and natural occurrence of the two phloem-restricted organisms. Gatineau et al. (13) have shown in a previous work that $P$. beieri can be a significant vector of stolbur to sugar beet. However, none of the assayed insects were positive for phytoplasma by PCR during the whole period of capture in 2000. The unique case of stolbur phytoplasma transmission nevertheless suggested the presence of phytoplasma-infected insects in wild populations, though at a very low level. In contrast, in 1997 and 1998, phytoplasma detection in captured populations was 13.3 and $11.8 \%$, respectively (13). Such fluctuation in the proportion of phytoplasma-infected insects in wild populations, according to the year, could be explained by interactions between the epidemiological cycle of phytoplasma and the biological cycle of the insect species. The only way insects can be infected by phytoplasma is by feeding on infected reservoir plants during the larval or adult stage. According to data on the biological cycle of $P$. beieri, stolbur phytoplasma acquisition might occur during the migratory flight of adults toward sugar beet plots (F. Gatineau, unpublished data). Infection rates could greatly fluctuate depending on the distance of migratory flight and on the presence of reservoir plants along the flight path.

The BLO-infected plants obtained during transmission experiments suggested that $P$. beieri is an effective vector of the BLO of SBR. The PCR test using Fra4-Fra5 primers, which detected the latter BLO in plants, could not be used for the specific detection of the BLO in insects. Zreik et al. (32) have shown that these primers amplify DNA from endocytobiotes of insects and thus may lead to false positive results. Therefore, the biology of BLO transmission by $P$. beieri can only be studied, for the moment, by transmission and biological assays. High ratios of BLO-infected plants were obtained during our transmission experiments: out of 27 batches of insects, $21(77.8 \%)$ succeeded in inoculating one or both partner test-plants. Consequently, these 21 batches contained at least one or several infective insects. These data suggest that BLO-infective insects could occur at a high rate in wild populations, that they could be very efficient vectors, or both. Transmission to both periwinkle and sugar beet occurred from week 24 (beginning of June) in both Sâone-et-Loire and Doubs until week 31 (beginning of August) in Sâone-et-Loire. This suggests that an adult Pentastiridius sp. is potentially BLO-infective throughout its entire stay on sugar beet. Moreover, some data indicate that early larval instars are infective (F. Gatineau, unpublished data).

The present work, together with epidemiological studies and transmission trials carried out over several years (13), identify $P$. beieri as an effective vector of both a stolbur phytoplasma and a BLO to sugar beet. At this time, P. beieri is the only insect known as a vector of both a phytoplasma and a BLO. Transmission assays with other insect species will be undertaken to detect alternative vectors of the SBR disease.

Etiology of SBR. Previous data on phytoplasma-infected sugar beet have been reported (25). Stolbur phytoplasma was detected in field sugar beet in 1997, 1998, and 1999 (F. Gatineau, unpublished data) when stolbur-infective insects were found in the same plots (13). However, the rate of stolbur-infected plants among all SBRaffected sugar beet never exceeded $12 \%$ (F. Gatineau, unpublished data). In contrast, we detected no stolbur phytoplasma in SBRaffected sugar beet in 2000 . It might be assumed that this is a consequence of the very low rate of stolbur infection of $P$. beieri populations in 2000. Altogether, the low rates in stolbur infection of SBR-affected plants observed for the several years of study do not support the hypothesis that stolbur phytoplasma is a primary etiological agent in SBR. The present report of a second phloemrestricted organism, a BLO that can naturally infect sugar beet and can be experimentally associated with symptoms similar to those of SBR, suggests a causal role of the BLO in SBR and explains that SBR-affected sugar beet plants could test PCR-negative for phytoplasma.

\section{ACKNOWLEDGMENTS}

This work was financially supported by Institut Technique de la Betterave Industrielle and Conseil Régional de Bourgogne. We thank M. Nicole (ORSTOM, Montpellier, France) and M. T. Cousin for helpful discussion on microscopy and histochemistry results; D. Dubois (Service Commun de Microscopie Electronique, INRA, Dijon, France) for technical assistance; M. Pommier (CIREF, Lanxade, France) and B. D. Bruton (USDA-ARS, Oklahoma) for providing BLO-infected strawberry plants and yellow vine DNA control, respectively; and V. GianinazziPearson for reviewing the manuscript.

\section{LITERATURE CITED}

1. Avila, F. J., Bruton, B. D., Fletcher, J., Sherwood, J. L., Pair, S. D., and Melcher, U. 1998. Polymerase chain reaction detection and phylogenetic characterization of an agent associated with Yellow Vine Disease of cucurbits. Phytopathology 88:428-436.

2. Beckman, C. H. 1964. Host responses to vascular infection. Annu. Rev. Phytopathol. 2:231-252.

3. Behncken, G. M., and Gowanlock, D. H. 1976. Association of a bacterium-like organism with rugose leaf curl disease of clovers. Aust. J. Biol. Sci. 29:137-146.

4. Bruton, B. D., Fletcher, J., Pair, S. D., Shaw, M., and Sittertz-Bhatkar, H. 1998. Association of a phloem-limited bacterium with yellow vine disease in cucurbits. Plant Dis. 82:512-520.

5. Caudwell, A., Larrue, J., Kuszala, C., and Bachelier, J. C. 1971. Pluralité des jaunisses de la vigne. Ann. Phytopathol. 3:97-107.

6. Cazelles, O. 1978. Mise en évidence, par fluorescence, des mycoplasmes dans les tubes criblés intacts isolés des plantes infectées. J. Phytopathol. 91:314-319.

7. Cousin, M. T., and Jouy, P. 1983. Différents processus d'utilisation du réactif de Hoechst, fluorochrome du DNA, en vue du diagnostic des mycoplasmoses végétales: Avantages et limites. Agronomie 3:496-497. 
8. Cousin, M. T., and Jouy, P. 1983. Recherches en vue de l'amélioration des techniques de coloration des mycoplasmes sur coupes semi-fines. Utilisation de colorants polychromatiques: Thionine-acridine orange et bleu de méthylène azur A-safranine. Agronomie 3:497.

9. Davis, M. J. 1991. Fastidious bacteria of plant vascular tissue and their invertebrate vectors. Pages 4026-4029 in: The Prokaryotes, A Handbook on the Biology of Bacteria, Ecophysiology, Isolation, Identification, Applications, vol. 4. Springer-Verlag, New York.

10. Deng, G., and Hiruki, C. 1991. Amplification of 16S rRNA genes from culturable and non culturable Mollicutes. J. Microbiol. Methods 14:5361.

11. Deysson, G. 1954. Eléments d'Anatomie des Plantes Vasculaires. Sedes, Paris.

12. Gahan, P. B. 1984. Plant Histochemistry and Cytochemistry. Academic Press, London.

13. Gatineau, F., Larrue, J., Clair, D., Lorton, F., Richard-Molard, M., and Boudon-Padieu, E. 2001. A new natural planthopper vector of stolbur phytoplasma in the genus Pentastiridius (Hemiptera: Cixiidae). Eur. J. Plant Pathol. 107:263-271.

14. Gourret, J. P. 1980. Cytologie des procaryotes en microscopie électronique. INRAP, Dijon.

15. Greber, R. S., and Gowanlock, D. H. 1979. Rickettsia-like and mycoplasma-like organisms associated with two yellow-types diseases of strawberries in Queensland. Aust. J. Agric. Res. 30:1101-1109.

16. Green, S. K., and Nienhaus, F. 1980. Further investigations on the 'latent rosette disease' of sugar beet. I. Symptomatology, cytological and histological observations. J. Plant Dis. Prot. 87:745-755.

17. Hopkins, D. L. 1977. Diseases caused by leafhopper-borne, rickettsialike bacteria. Annu. Rev. Phytopathol. 17:277-294.

18. Jagoueix, S., Bové, J. M., and Garnier, M. 1994. The phloem-limited bacterium of greening disease of citrus is a member of the $\alpha$ subdivision of the Proteobacteria. Int. J. Syst. Bact. 44:379-386.

19. Lorenz, K. H., Schneider, B., Ahrens, U., and Seemüller, E. 1995. Detection of the apple proliferation and pear decline phytoplasmas by PCR amplification of ribosomal and non ribosomal DNA. Phytopathology 85:771-776.

20. Markham, P. G., Townsend, R., and Plaskitt, K. A. 1975. A rickettsia-like organism associated with diseased white clover. Ann. Appl. Biol. 81:91-93.

21. McCoy, R. E., Caudwell, A., Chang, C. J., Chen, T. A., Chiykowski, L. N., Cousin, M. T., Dale, J. L., de Leeuw, G. T. N., Golino, D. A.,
Hackett, K. J., Kirkpatrick, B. C., Marwitz, R., Petzold, H., Sinha, R. C., Sugiura, M., Whitcomb, R. F., Yang, I. L., Zhu, B. M., and Seemüller, E. 1989. Plant diseases associated with mycoplasma-like organisms. Pages 545-640 in: The Mycoplasmas. Vol. 5. R. F. Whitcomb and J. G. Tully, eds. Academic Press, San Diego, CA.

22. Nienhaus, F. 1976. Rickettsialike organisms in latent rosette (witches' broom) diseased sugar beet (Beta vulgaris) and spinach (Spinacia oleracea) plants and in the vector Piesma quadratum Fieb. J. Plant Dis. Prot. 83:641-646.

23. Nourrisseau, J. G., Lansac, M., and Garnier, M. 1993. Marginal chlorosis, a new disease of strawberries associated with a bacteriumlike organism. Plant Dis. 77:1055-1059.

24. Reynolds, E. S. 1963. The use of lead citrate at high $\mathrm{pH}$ as an electronopaque stain in electron microscopy. J. Cell Biol. 17:208-212.

25. Richard-Molard, M., Garressus, S., Malatesta, G., Orny, G., Valentin, P., Reinbold, C., Gerst, M., Blech, F., Fonne, G., Putz, C., Grousson, C., and Boudon-Padieu, E. 1995. Le syndrome des basses richesses-Investigations au champ et tentatives d'identification de l'agent pathogène et du vecteur. Pages 299-309 in: Proc. 58ème Congrès de l'Institut International de Recherches Betteravières, Dijon-Beaune, France.

26. Schmutterer, H., and Lorra, C. 1976. Eine neue Krankheit der BetaRüben. Z. Pflanzenkrankh. Pflanzenschutz. 83:295-298.

27. Seemüller, E., Marcone, C., Lauer, U., Ragozzino, A., and Göschl, M. 1998. Current status of molecular classification of the phytoplasmas. J. Plant Pathol. 80:3-26.

28. Seemüller, E. T. 1976. Fluoreszenzoptischer direktnachweis von mykoplasmaähnlichen organismen im phloem pear decline und triebsuchtkranker baüme. Phytopathol. Z. 85:368-372.

29. Smart, C. D., Schneider, B., Blomquist, C. L., Gerra, L. J., Harrison, N. A., Ahrens, U., K. H., L., Seemüller, E., and Kirkpatrick, B. C. 1996. Phytoplasma-specific PCR primers based on sequences of the 16S rRNA spacer region. Appl. Environ. Microbiol. 62:2988-2993.

30. Thiéry, J. P. 1967. Mise en évidence des polysaccharides sur coupes fines en microscopie électronique. J. Microsc. 6:987-1018.

31. Urbina-Vidal, C., and Hirumi, H. 1974. Search for causative agents of the sugar beet Yellow wilt in Chile. J. ASSBT 18:142-162.

32. Zreik, L., Bové, J. M., and Garnier, M. 1998. Phylogenetic characterization of the bacterium-like organism associated with marginal chlorosis of strawberry and proposition of a Candidatus taxon for the organism, 'Candidatus Phlomobacter fragaria'. Int. J. Syst. Bacteriol. 48:257-261. 